Research article

Open Access

\title{
Immunization with an immunodominant self-peptide derived from glucose-6-phosphate isomerase induces arthritis in DBA/1 mice
}

\author{
Lisa Bruns ${ }^{1}$, Oliver Frey ${ }^{1}$, Lars Morawietz² ${ }^{2}$, Christiane Landgraf ${ }^{3}$, Rudolf Volkmer ${ }^{3}$ and \\ Thomas Kamradt 1
}

\author{
1 Universitätsklinikum Jena, Institut für Immunologie, Leutragraben 3, Jena 07740, Germany \\ ${ }^{2}$ Charité Universitätsmedizin Berlin, Institut für Pathologie, Charitéplatz 1, Berlin 10117, Germany \\ ${ }^{3}$ Charité Universitätsmedizin Berlin, Institut für Medizinische Immunologie, Charitéplatz 1, Berlin 10117, Germany \\ Corresponding author: Thomas Kamradt, thomas.kamradt@mti.uni-jena.de
}

Received: 17 Nov 2008 Revisions requested: 15 Dec 2008 Revisions received: 23 Jun 2009 Accepted: 29 Jul 2009 Published: 29 Jul 2009

Arthritis Research \& Therapy 2009, 11:R117 (doi:10.1186/ar2777)

This article is online at: http://arthritis-research.com/content/11/4/R117

(c) 2009 Bruns et al.; licensee BioMed Central Ltd.

This is an open access article distributed under the terms of the Creative Commons Attribution License (http://creativecommons.org/licenses/by/2.0), which permits unrestricted use, distribution, and reproduction in any medium, provided the original work is properly cited.

\begin{abstract}
Introduction T-helper (Th) lymphocytes are critically required for the pathogenesis of glucose-6-phosphate isomerase (G6Pl)induced arthritis, but neither the G6PI epitopes recognized by arthritogenic $T$ cells nor their pathogenic effector functions have been fully elucidated to date. We aimed at identifying arthritogenic G6PI peptides.
\end{abstract}

Methods We used a library of overlapping peptides spanning the entire G6PI sequence to identify the epitopes recognized by G6PI-specific Th cells. Immunodominant peptides were then used to immunize mice. Arthritis development was evaluated clinically and histologically. The humoral and cellular immune responses upon peptide immunization were analyzed by ELISA and multiparameter flow cytometry, respectively.
Results We identified six immunodominant T-cell epitopes in $\mathrm{DBA} / 1$ mice, of which three are arthritogenic. One of these peptides $\left(\mathrm{G}_{6 \mathrm{Pl}} \mathrm{469-483}\right)$ is identical in man and mice. Immunization with this peptide induces arthritis, which is less severe and of shorter duration than arthritis induced by immunization with full-length G6PI. Upon immunization with either G6PI or peptide, the antigen-specific Th cells produce IL17, RANKL, IFN $\gamma$ and TNF $\alpha$.

Conclusions We identified immunodominant and arthritogenic epitopes of G6PI. Not all immunodominant peptides are arthritogenic. This is the first description of arthritis induced by immunization with a self-peptide in mice.

\section{Introduction}

Autoreactive CD4+ T-helper (Th) lymphocytes play a central role in the pathogenesis of autoimmune diseases [1]. Key to the development of immune responses is the binding of T-cell receptors on $\mathrm{CD}^{+}{ }^{+} \mathrm{Th}$ cells to their cognate peptide/MHC complex on the surface of antigen-presenting cells (APC). Among the well-established genetic risk factors for rheumatoid arthritis, HLA-DRB1, PTPN22 and STAT4 are relevant for T-cell function [2-4]. T cells are present in the inflamed synovial compartment $[5,6]$. These findings strongly suggest the concept that rheumatoid arthritis is Th-cell dependent, and that the associated HLA-DR molecules present peptides to autoreactive Th cells, which initiate the inflammatory process that ultimately leads to rheumatoid arthritis. This assumption is supported by the clinical benefits of treating rheumatoid arthritis patients with abatacept, a CTLA4-immunoglobulin fusion protein that blocks Th-cell costimulation, thus selectively inhibiting their activation $[7,8]$. Nevertheless, the specificity of the pathogenic Th cells in rheumatoid arthritis has been difficult to define.

In experimental animals, arthritis can be induced by systemic immunization with noncartilagenous antigens $[9,10]$ or with cartilage-antigens including heterologous collagen type II [11], collagen type XI [12], cartilage oligomeric matrix protein [13] and proteoglycan [14] in complete Freund's adjuvant (CFA). The immune response of $\mathrm{T}$ cells to complex antigens is commonly focused on a small number of major epitopes.

APC: antigen-presenting cells; CFA: complete Freund's adjuvant; ELISA: enzyme-linked immunosorbent assay; FCS: fetal calf serum; G6PI: glucose6-phosphate-isomerase; H \& E: hematoxylin and eosin; IFN: interferon; IL: interleukin; mAb: monoclonal antibody; RANKL: receptor activator of NFк $\beta$ ligand; Th: T-helper. 
Although immunodominant collagen type II epitopes have been defined for different collagen-induced arthritis-susceptible strains of mice [11,15], and for proteoglycan [16], experimental arthritis cannot be induced by immunization with these immunodominant peptides $[15,16]$. In fact, even denatured collagen type II or its cyanobromide fragments are less efficient for arthritis induction than full-length, native collagen type II [17]. This lack of an identified arthritogenic epitope has been an obstacle to studying the role of Th cells in mouse models of arthritis. Collagen-induced arthritis is easily transferable with serum from arthritic animals or mixtures of monoclonal antibodies specific for collagen type II, reflecting a strong dependence on antibodies [18-20].

We recently described a model in which systemic immune responses to glucose-6-phosphate isomerase (G6PI) induce a peripheral symmetric polyarthritis in susceptible strains of mice $[21,22]$. In this model, arthritis development depends on T cells, B cells and innate immunity [21-25]. CD4+ Th cells are crucial not only for the induction of the disease but also during the effector phase. Depletion of CD4 ${ }^{+} \mathrm{T}$ cells in arthritic animals induces arthritis remission [21]. To understand better the role of Th cells in this model, we sought to determine the immunodominant epitopes in G6Pl-induced arthritis. In the present article we describe the identification of six immunodominant G6PI epitopes and the induction of arthritis in DBA/1 mice by immunization with three of these peptides.

\section{Materials and methods Animals and arthritis induction}

DBA/1 mice were bred and maintained under specific-pathogen free conditions in our animal facility. All animal experiments were approved by the Government Commission for Animal Protection (Registered Number 02-005/06).

Arthritis was induced in 6-week-old to 10-week-old DBA/1 mice by subcutaneous immunization at the base of the tail with either $400 \mu \mathrm{g}$ recombinant human G6PI or $50 \mu \mathrm{g}$ peptide in complete Freund's adjuvant (Sigma-Aldrich, Taufkirchen, Germany).

Clinical scores were determined daily for each paw independently, as previously described [21]. A score of 0 indicates no clinical signs of arthritis, 1 indicates slight swelling and redness, 2 indicates a strong swelling and redness, and 3 indicates massive swelling and redness. Arthritis incidence is almost $100 \%$ in this model, and the natural history is highly synchronized with arthritis onset on $\mathrm{d} 9$.

\section{Antibodies and reagents}

The following mAbs were grown and purified from hybridoma supernatants in our laboratory: anti-CD16/CD32 (2.4G2) and anti-CD28 (37.51). Anti-IL-17A (eBio17B7)-Alexa 488, antiTNF $\alpha$ (MP6-XT22)-Pacific Blue, anti-IFN $\gamma$ (XMG1.2)-phycoerythrin-Cy7, anti-CD4 (RM4-5)-allophycocyanin-Alexa750
(APC-A750), anti-IL-2 (JES6-5H4)-fluorescein isothiocyanate, anti-IL-6 (MP5-20F3)-fluorescein isothiocyanate, anti-IL-10 (JES5-16E3)-APC, and anti-RANKL (IK22/5)-phycoerythrin were purchased from ebiosciences (San Diego, CA, USA). Anti-CD154 (MR1)-APC was purchased from Miltenyi Biotec (Bergisch Gladbach, Germany). Recombinant human G6PI was expressed in Escherichia coli BL21 as described previously [21].

\section{Peptides}

Cellulose-bound peptides were prepared according to the standard SPOT synthesis protocol by a MultiPep SPOT-robot (INTAVIS Bioanalytical instruments AG, Köln, Germany) on a $\beta$-alanine-modified cellulose membrane as described elsewhere [26].

Each spot was eluted in $200 \mu$ distilled $\mathrm{H}_{2} \mathrm{O}$ containing $5 \%$ dimethylsulfoxide, resulting in an approximate concentration of 350 to $650 \mu \mathrm{g} / \mathrm{ml}$ peptide solution. These peptide solutions were taken to create peptide pools resulting in a concentration of any single peptide of $\sim 42 \mu \mathrm{g} / \mathrm{ml}$. The final concentration for in vitro restimulation for every single peptide was $\sim 1 \mu \mathrm{g} / \mathrm{ml}$. Peptides for immunization were synthesized according to standard Fmoc machine protocols with the multiple peptide synthesizer SYRO II (MultiSynTec, Witten, Germany). The following peptides derived from human G6PI were synthesized: $\mathrm{G} \mathrm{PI}_{65-79}$ (MRMLVDLAKSRGVEA), $\mathrm{G}_{6 \mathrm{PI}}{ }_{85-99}$ (FNGEKINYTEGRAVL), G6PI ${ }_{325-339}$ (IWYINCFGCETHAML), ${\mathrm{G} 6 P I_{469-483}}_{4}(E G N R P T N S I V F T K L T)$, G6PI $_{497-511}$ (KIFVQGIlWDINSFD) and G6PI $_{517-531}$ (LGKQLAKKIEPELDG). Purity of the peptides was determined by high-performance liquid chromatography and the composition was monitored by matrixassisted laser desorption/ionization time-of-flight mass spectroscopy.

\section{Histopathology}

Microsections from mouse legs were prepared and stained with $\mathrm{H}$ \& $\mathrm{E}$ as described previously [21]. Samples were viewed with a DMRBE microscope (Leitz, Wetzlar, Germany) by a pathologist who was blinded to the experimental setup. The severity was graded semiquantitatively in five steps from 0 (normal finding) to 4 (strong inflammation) as described previously $[21,27]$.

\section{Proliferation assays}

All cell cultures and assays were performed in RPMI 1640 supplemented with $10 \%$ FCS, $100 \mathrm{U} / \mathrm{ml}$ penicillin, $100 \mu \mathrm{g} / \mathrm{ml}$ streptomycin, and $50 \mu \mathrm{M}$ 2-mercaptoethanol as described [21].

Cells were plated in a 96-well round-bottom plate (Greiner Bio-One, Solingen, Germany) at a density of $1 \times 10^{6} \mathrm{cells} / \mathrm{ml}$ culture medium. Cells were stimulated with either $10 \mu \mathrm{g} / \mathrm{ml}$ G6PI, $5 \mu$ peptide pool or culture medium alone in triplicate for 72 hours. For the last 18 hours $1 \mu \mathrm{Ci} /$ well $\left[{ }^{3} \mathrm{H}\right]$ thymidine 
(GE Healthcare, München, Germany) was added. [3H]thymidine incorporation was measured with a $\beta$-scintillation counter. Results are displayed as the stimulation index, which is the quotient of the mean counts of cells that were stimulated and the mean count of cells cultured in medium alone. Results were considered positive if the stimulation index was at least 2 and the difference between the stimulated and the nonstimulated sample was more than 1,000 counts per minute.

\section{Flow cytometry}

Single-cell suspensions from draining lymph nodes (inguinal, para-aortic, $1 \times 10^{7} \mathrm{cell} / \mathrm{s} / \mathrm{ml}$ ) were cultured in 48-well plates in the presence of $3 \mu \mathrm{g} / \mathrm{ml}$ anti-CD28 and either $20 \mu \mathrm{g} / \mathrm{ml} \mathrm{G6PI}$, $5 \mu \mathrm{g} / \mathrm{ml}$ peptide or medium alone for 6 hours. Brefeldin A (Sigma-Aldrich) was added to a final concentration of $5 \mu \mathrm{g} / \mathrm{ml}$ for the last 4 hours. Since CD154 upregulation occurs exclusively upon T-cell receptor signaling (and not upon bystander activation of $\mathrm{T}$ cells), possible lipopolysaccharide contamination of the antigen preparation does not influence this assay (data not shown). Cells were stained with a viability dye (Aqua fixable live/dead staining kit; Invitrogen, Karlsruhe, Germany) according to the manufacturer's instructions. After fixation with 2\% paraformaldehyde for 20 minutes, cells were permeabilized with $0.5 \%$ saponin (Sigma-Aldrich) and incubated with anti-CD16/32 $(2.4 \mathrm{G} 2 / 75 ; 100 \mu \mathrm{g} / \mathrm{ml})$ and rat lgG $(200 \mu \mathrm{g} /$ $\mathrm{ml}$; Dianova, Hamburg, Germany) to prevent unspecific binding. Cells were stained for CD4, CD154 and cytokines. A seven-color panel was used to simultaneously analyze multiple cytokines on CD4+CD154+ $\mathrm{T}$ cells using a BD LSR II flow cytometer (BD Biosciences, Heidelberg, Germany); $3,000,000$ events were acquired for each sample.

Data were analyzed using FlowJo Software (TreeStar, Ashland, Oregon, USA). Doublets were excluded using forward scatter-area versus forward scatter-height parameters, followed by the selection of lymphocytes and live cells (Aqua-). Gates for CD154 were set using unstimulated control samples and gates for cytokine-positive cells were set using fluorescence-minus-one controls for the respective cytokine $[28,29]$.

\section{Anti-G6PI-immunoglobulin ELISA}

Titers of G6PI-specific antibodies were measured by ELISA as previously described [21]. Fourfold serial dilutions of the sera were incubated on G6PI-coated ELISA plates (Greiner, Frickenhausen, Germany) and bound immunoglobulins were detected with the mouse monoclonal isotyping kit (SigmaAldrich, Crailshaim, Germany). o-Phenylendiamine was used as the substrate, and the optical density was measured at 492 $\mathrm{nm}$.

\section{Statistical analysis}

All data are presented as the mean \pm standard error of the mean unless otherwise indicated. Statistical analysis (non-par- ametric Mann-Whitney $U$ test) was performed with SPSS 15.0 (SPSS Inc., Chicago, IL, USA).

\section{Results \\ Mapping the immunodominant T-cell epitopes in G6PI- induced arthritis}

To determine the immunodominant G6PI T-cell epitopes, we immunized DBA/1 mice with G6PI and examined T-cell proliferation in response to recombinant $\mathrm{G} 6 \mathrm{PI}$ and a set of 137 overlapping 15 mer peptides spanning the entire amino acid sequence of human G6PI (Figure 1a). For high-efficiency screening we designed 24 two-dimensional peptide pools such that each peptide was contained in two different pools (Figure 1b). Recombinant G6PI induced intensive T-cell proliferation (Figure 1c).

Peptide pools that induced a stimulation index $\geq 2$ were considered to contain a T-cell epitope. Pools 10 and 14 induced stimulation indexes $>2$ in all three experiments performed. Therefore, peptide $22\left(\mathrm{G}_{6 \mathrm{Pl}}{ }_{85-99}\right)$, which is contained in both Pools 10 and 14 (Figure $1 \mathrm{~b}$ ), scored positive in all three experiments. Peptide 17 ( $6 \mathrm{Pl}_{65-79}$, contained in Pools 5 and 14), peptide 118 (G6PI $_{469-483}$, contained in Pools 10 and 22), peptide 125 (G6PI $_{497-511}$, contained in Pools 5 and 23) and peptide $130\left(\mathrm{G}_{6 \mathrm{PI}}{ }_{517-531}\right.$, contained in Pools 10 and 23) scored positive in two out of three experiments (Figure 1b). In addition, several peptides yielded positive results in only one of the experiments (Figure 1b). Those five peptides that scored positive in at least two of the three experiments were chosen for further analysis.

While the present manuscript was in preparation, Iwanami and colleagues reported that $\mathrm{G}_{6 \mathrm{PI}} \mathrm{325-339}$ was arthritogenic [30]. We therefore synthesized $\mathrm{G}_{6 \mathrm{PI}} \mathrm{325-339}$, which is our peptide 82 and scored positive in one of three screening experiments, and performed additional experiments including this peptide.

\section{Immunization of DBA/1 mice with G6PI-derived peptides induces arthritis}

Immunization of DBA/1 mice with full-length $\mathrm{G} 6 \mathrm{PI}$ in CFA induces arthritis with a high incidence $(>95 \%$ of the immunized animals) and a synchronized clinical course, with disease onset at day 9 after immunization, a peak of clinical symptoms between days 12 and 20, and a slow resolution from day 21 onwards. We asked whether immunization with the five peptides identified by our screening and with the peptide identified by Iwanami and colleagues [30] also induced arthritis. In several independent experiments, which are summarized in Table 1, immunization with all six G6PI peptides induced arthritis - albeit of different incidence and severity. Immunization with $\mathrm{G}_{6 \mathrm{PI}}{ }_{65-79}, \mathrm{G} 6 \mathrm{PI}_{497-511}$ and $\mathrm{G}_{6 \mathrm{PI}}{ }_{517-531}$ induced arthritis with varying and comparatively low incidence. Duration of arthritis was short and clinical symptoms were only mild (Table 1). In contrast, immunization with $\mathrm{G}_{6 \mathrm{PI}} \mathrm{P5-99}_{\text {, }}$ $\mathrm{G}_{6 \mathrm{PI}} \mathrm{325-339}$ and $\mathrm{G}_{6 \mathrm{PI}}{ }_{469-483}$ reproducibly induced arthritis 
Figure 1

$\begin{array}{lcl}\text { (a) peptide } 1 & \text { MAALTRDPQFQKLQQ } & \text { huG6PI } \\ \text { peptide } 2 & \text { TRDPQFQKLQQWYRE huG6PI } & \\ & \text { Overlap = 11 aa }\end{array}$

(b)

\begin{tabular}{|l|r|r|r|r|r|r|r|r|r|r|r|r|}
\hline Pool & $\mathbf{1}$ & $\mathbf{2}$ & $\mathbf{3}$ & $\mathbf{4}$ & $\mathbf{5}$ & $\mathbf{6}$ & $\mathbf{7}$ & $\mathbf{8}$ & $\mathbf{9}$ & $\mathbf{1 0}$ & $\mathbf{1 1}$ & $\mathbf{1 2}$ \\
\hline $\mathbf{1 3}$ & 1 & 2 & 3 & 4 & 5 & 6 & 7 & 8 & 9 & $\mathbf{1 0}$ & 11 & 12 \\
\hline $\mathbf{1 4}$ & 13 & 14 & 15 & 16 & $\mathbf{1 7}$ & $\mathbf{1 8}$ & 19 & 20 & 21 & $\mathbf{2 2}$ & 23 & 24 \\
\hline $\mathbf{1 5}$ & 25 & 26 & 27 & 28 & 29 & 30 & 31 & 32 & 33 & 34 & 35 & 36 \\
\hline $\mathbf{1 6}$ & 37 & 38 & 39 & 40 & 41 & 42 & 43 & 44 & 45 & 46 & 47 & 48 \\
\hline $\mathbf{1 7}$ & 49 & 50 & 51 & 52 & $\mathbf{5 3}$ & 54 & 55 & 56 & 57 & $\mathbf{5 8}$ & 59 & 60 \\
\hline $\mathbf{1 8}$ & 61 & 62 & 63 & 64 & $\mathbf{6 5}$ & 66 & 67 & 68 & 69 & $\mathbf{7 0}$ & 71 & 72 \\
\hline $\mathbf{1 9}$ & 73 & 74 & 75 & 76 & $\mathbf{7 7}$ & 78 & 79 & 80 & 81 & $\mathbf{8 2}$ & 83 & 84 \\
\hline $\mathbf{2 0}$ & 85 & 86 & 87 & 88 & $\mathbf{8 9}$ & 90 & 91 & 92 & 93 & $\mathbf{9 4}$ & 95 & 96 \\
\hline $\mathbf{2 1}$ & 97 & 98 & 99 & 100 & 101 & 102 & 103 & 104 & 105 & 106 & 107 & 108 \\
\hline $\mathbf{2 2}$ & 109 & 110 & 111 & 112 & $\mathbf{1 1 3}$ & 114 & 115 & 116 & 117 & $\mathbf{1 1 8}$ & 119 & 120 \\
\hline $\mathbf{2 3}$ & 121 & 122 & 123 & 124 & $\mathbf{1 2 5}$ & 126 & 127 & 128 & 129 & $\mathbf{1 3 0}$ & 131 & 132 \\
\hline $\mathbf{2 4}$ & 133 & 134 & 135 & 136 & 137 & & & & & & & \\
\hline
\end{tabular}

(c)

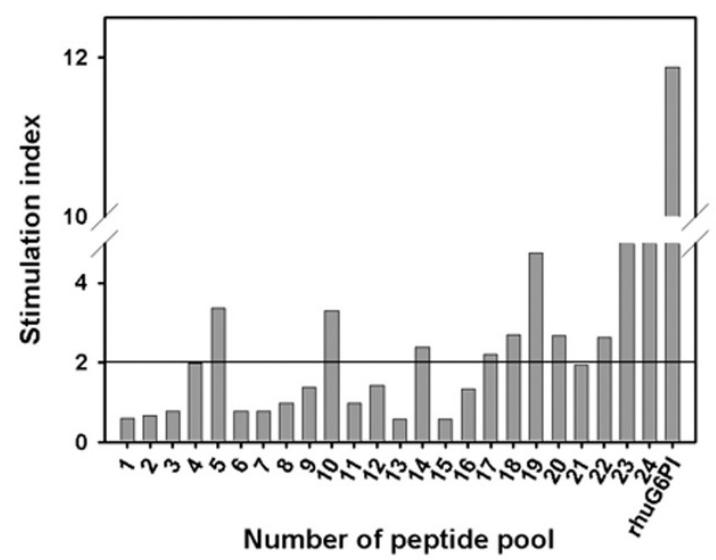

T-cell epitope mapping. (a) The peptide library covering the entire human glucose-6-phosphate-isomerase (G6PI) sequence contained 137 peptides of 15 amino acids length, overlapping by 11 amino acids (aa). (b) Epitope mapping with two-dimensional peptide pools. Pools are represented by horizontal lines or vertical columns (white numbers on black background). For example, Pool 14 contains peptides 13 through 24 (numbers on white background). Each peptide is represented in two pools. For example, peptide 22 is represented in Pools 10 and 14 . For epitope mapping, DBA/1 mice were immunized with $100 \mu \mathrm{g} \mathrm{G6PI}$ in complete Freund's adjuvant ( $n=3$ per experiment). Single-cell suspensions were prepared from draining lymph nodes and the spleen 12 days after immunization, and proliferation assays were performed as described in Materials and methods. Three independent experiments were performed. The one peptide (peptide 22) that scored positive in all three experiments is highlighted in bold italic; peptides identified in two experiments are highlighted by bold underlined numerals (peptides 17, 118,125 and 30); peptides identified in only one experiment are highlighted in bold and the other peptides are given in grey. (c) Results from one exemplary experiment are shown. Results are displayed as the stimulation index. A stimulation index $>2$ was considered positive.

with an incidence between 79 and 100\%. Onset of arthritis was delayed, the clinical scores were significantly lower $(P<$ 0.05 for $\mathrm{G} 6 \mathrm{PI}$-immunized vs. all peptide immunized groups), and the disease was of shorter duration in the peptide-immu- nized mice compared with the mice immunized with full-length G6PI (Figure 2a).

Histopathological analysis revealed typical signs of arthritis in both peptide-immunized and protein-immunized mice (Figure 
(a)

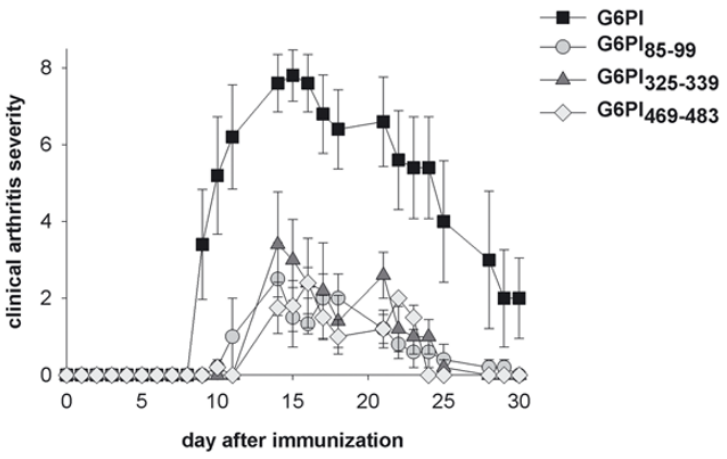

(b)
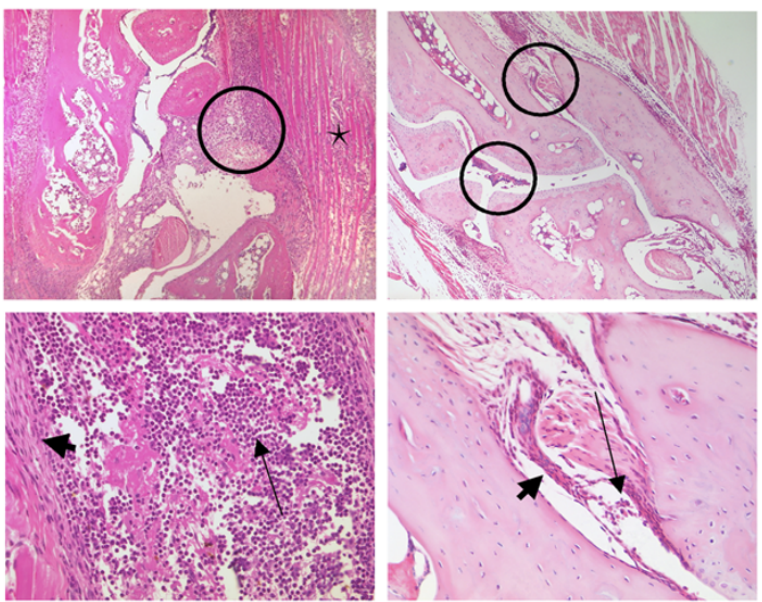

G6PI

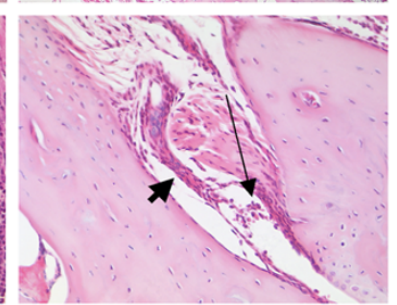

G6PI
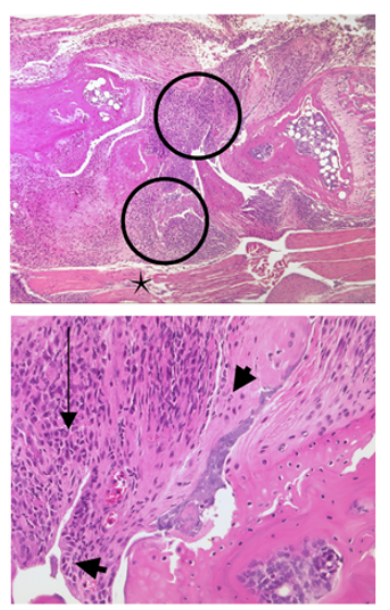

G6PI

Immunization of DBA/1 mice with glucose-6-phosphate-isomerase-derived peptides induces arthritis. (a) Mice were immunized with either $400 \mu \mathrm{g}$ glucose-6-phosphate-isomerase (G6PI), $50 \mu \mathrm{g} \mathrm{G} \mathrm{PPI}_{85-99}, 50 \mu \mathrm{g} \mathrm{G} \mathrm{PI}_{325-339}$ or $50 \mu \mathrm{g} \mathrm{G}_{6 \mathrm{PI}_{469-483}}$ in complete Freund's adjuvant. Shown is the clinical severity of disease in arthritic mice in a representative experiment ( $n=5$ per group). Each peptide was tested in at least two independent experiments (Table 1). (b) The animals immunized with G6PI showed a strong synovialitis (circles) and inflammation of the adjacent skeletal muscle (star), which was dominated by neutrophilic granulocytes (small arrow) as a sign of acute inflammation and exhibited activation of synovial fibroblasts to a lesser extent (broad arrow). The synovial tissue was enlarged due to the dense inflammatory infiltrate; however, bone destruction was only focally observed. Similar but markedly less intense alterations could be observed in the animals immunized with $\mathrm{G}_{6 \mathrm{PI}} \mathrm{85-99}$, whereas immunization with peptide $\mathrm{G}_{6 \mathrm{PI}}{ }_{469-483}$ resulted in an inflammation that was as strong as when using whole $\mathrm{G} 6 \mathrm{PI}$. (H \& E; original magnification: upper row, 50x; lower row, 200x). Results show representative data from at least nine individual mice from two typical experiments.

2b). Confirming our earlier findings, arthritis was almost exclusively localized to the phalangeal and tarsal joints, whereas the knee joints were rarely and only mildly affected. In most animals, the legs were symmetrically involved, and there was no predilection for the front or the hind limbs.

The inflammation involved the synovial fluid and synovial membrane (Figure 2b, upper row, encircled areas) and extended into the adjacent structures, comprising tendons and tendon sheaths, ligaments and muscles (Figure 2b, upper row, stars), and in the most severe cases it also affected the subcutaneous tissue and skin.

At day 12 the signs of acute and chronic inflammation were similarly developed, with a slight predominance for features of acute arthritis. In the joints of all animals, infiltrating neutrophilic granulocytes could be detected - in the more severe cases with formation of abscesses (Figure 2b, left column) and purulent joint effusion, and with fibrin exudation (Figure $2 b$, lower row, long arrows).

In contrast, cell types typical of chronic inflammation like lymphocytes, plasma cells and macrophages were found to a lesser extent (Figure 2b, lower row, arrowheads). No formation of multinucleated giant cells and no granulomas could be observed. A thickening of the synovial lining and a dense proliferation of fibroblasts were observed (Figure 2b, lower row, arrowheads), however, comparable with the pannus formation in human rheumatoid arthritis. 
Table 1

\begin{tabular}{|c|c|c|}
\hline Peptide & Arthritic mice per experiment & Cumulative incidence (\%) \\
\hline \multirow[t]{3}{*}{$\mathrm{G} \mathrm{PI}_{65-79}$} & $3 / 5$ & 60 \\
\hline & $5 / 5$ & \\
\hline & $1 / 5$ & \\
\hline \multirow[t]{7}{*}{$\mathrm{G}_{6 \mathrm{PI}}{ }_{85-99}$} & $5 / 5$ & 79 \\
\hline & $8 / 10$ & \\
\hline & $5 / 5$ & \\
\hline & $4 / 8$ & \\
\hline & $4 / 5$ & \\
\hline & $5 / 5$ & \\
\hline & $3 / 5$ & \\
\hline \multirow[t]{2}{*}{$\mathrm{G}_{6 \mathrm{PI}}{ }_{325-339}$} & $5 / 5$ & 100 \\
\hline & $4 / 4$ & \\
\hline \multirow[t]{4}{*}{$\mathrm{G} 6 \mathrm{PI}_{469-483}$} & $5 / 5$ & 95 \\
\hline & $7 / 8$ & \\
\hline & $5 / 5$ & \\
\hline & $5 / 5$ & \\
\hline \multirow[t]{3}{*}{$\mathrm{G} \mathrm{PI}_{497-511}$} & $3 / 5$ & 53 \\
\hline & $5 / 5$ & \\
\hline & $0 / 5$ & \\
\hline \multirow[t]{3}{*}{$\mathrm{G} \mathrm{PI}_{517-531}$} & $1 / 5$ & 40 \\
\hline & $5 / 5$ & \\
\hline & $0 / 5$ & \\
\hline
\end{tabular}

Taken together, our data show that three of the peptides were robustly arthritogenic, whereas immunization with the other three peptides resulted only in a slight arthritis induction. We therefore restricted the following analyses of the T-cell and Bcell responses to the arthritogenic peptides $\mathrm{G}_{6 \mathrm{PI}} \mathrm{B5}_{89}$, $\mathrm{G}_{6 \mathrm{PI}_{325-339}}$ and $\mathrm{G}_{6 \mathrm{PI}_{469-483}}$.

\section{Ex vivo cytokine production after immunization with G6PI or arthritogenic peptides}

To identify G6PI-specific or peptide-specific T cells we used intracellular staining of CD154 after a brief restimulation of ex vivo isolated draining lymph node cells with full-length $\mathrm{G} 6 \mathrm{PI}$ or the respective peptide. CD154 expression is strictly dependent on T-cell receptor engagement, and therefore expression of CD154 identifies antigen-specific cells in ex vivo stimulation assays $[28,29]$.

We first analyzed the total number of CD154+CD4+ cells from the draining lymph nodes at day 12 after immunization, and found no statistically significant difference between G6PI- immunized or peptide-immunized mice (Figure 3a, b). Next we examined the cytokine production of the CD154+ antigen-specific $T$ cells. As shown in Figure $3 c$, the most abundant cytokine in all groups was IL-17, followed by TNF $\alpha$ and RANKL or IFN $\gamma$. The frequency of antigen-specific IL-2-producing, IL-4-producing or IL-6-producing $\mathrm{T}$ cells was extremely low, and IL-10-producing Th cells were never detected in G6Pl-immunized mice (data not shown).

Compared with mice immunized with full-length G6PI, peptide-immunized mice showed a more prominent cytokine response. It is important to note here that the T-cell response develops much faster in the animals immunized with full-length $\mathrm{G} 6 \mathrm{PI}$, with a maximum response at day 9 , compared with the peptide-immunized mice, in which the peak response is at day 12 after immunization ([21] and data not shown). 


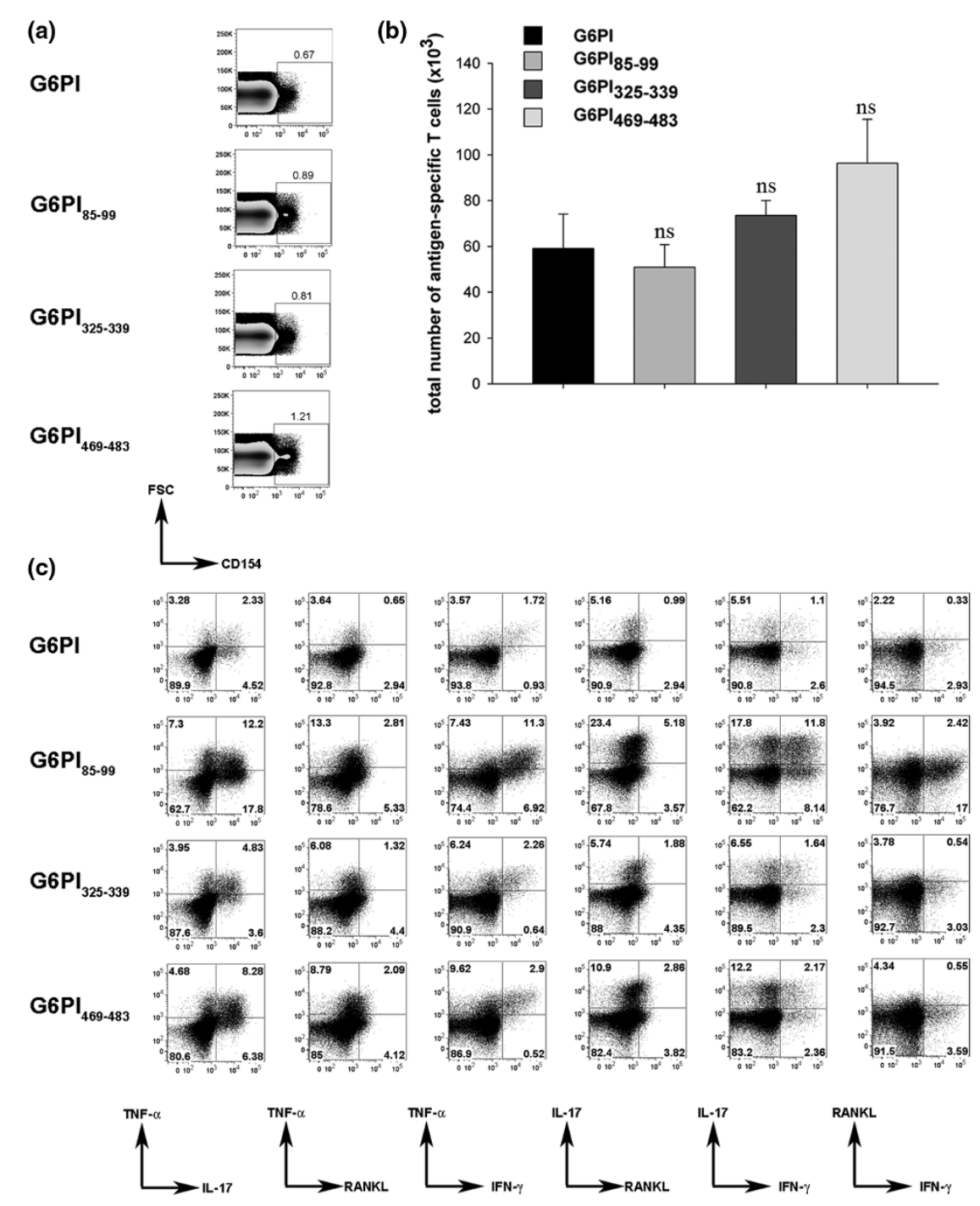

T-cell response after immunization with glucose-6-phosphate isomerase or arthritogenic peptides. DBA/1 mice were immunized with $400 \mu \mathrm{g}$ glucose-6-phosphate-isomerase (G6PI), $50 \mu \mathrm{g} \mathrm{G} \mathrm{PI}_{85-99}, 50 \mu \mathrm{g} \mathrm{G} \mathrm{PI}_{325-339}$ or $50 \mu \mathrm{g} \mathrm{G6PI} 469-483$ in complete Freund's adjuvant. Mice were sacrificed on day 12 after immunization and single-cell suspensions from draining lymph nodes were prepared. Cells were stimulated with same antigen as used for immunization ( $20 \mu \mathrm{g} / \mathrm{ml} \mathrm{G6Pl}$ or $5 \mu \mathrm{g} / \mathrm{ml}$ peptide). (a) Antigen-specific CD4+ cells were identified by CD154 expression as described in Materials and methods. Numbers above the gates indicate the percentage of CD154+ cells. (b) Total numbers of antigen-specific CD4+ cells were calculated by multiplication of the total number of lymph node cells with the frequency of CD4+CD154+ cells. (c) Intracellular staining for TNF $\alpha$, IL17, RANKL and IFN $\gamma$. Dot plots show the expression of these cytokines in antigen-specific T cells (gated on CD4 ${ }^{+} \mathrm{CD} 154^{+}$cells). Numbers in quadrants indicate the percentage of cells producing the respective cytokines within the antigen-specific T-cell compartment. Data depicted in (a) and (c) are from concatenated data files from five individual mice per group and represent all mice in the respective group. This experiment was performed at least two times. FSC, forward scatter; ns, nonsignificant; $P>0.05$ between G6Pl-immunized vs. peptide-immunized mice.

\section{G6PI-specific immunoglobulins after immunization with G6PI or immunodominant peptides}

Since we have previously shown that B-cell responses are important for the pathogenesis of $\mathrm{G} 6 \mathrm{Pl}$-induced arthritis $[21,22]$, sera of the mice were tested for the presence of G6PI-specific immunoglobulins. As expected, immunization with full-length G6PI resulted in high titers of all isotypes except IgA (Figure 4). In mice immunized with $\mathrm{G}_{6 \mathrm{PI}} \mathrm{P}_{8599}$ or $\mathrm{G}_{6 \mathrm{PI}} \mathrm{H69-483}$ we detected only $\mathrm{G} 6 \mathrm{PI}$-specific IgM, albeit at much lower concentrations than in G6Pl-immunized mice. We additionally detected small amounts of $\mathrm{G} 6 \mathrm{PI}$-specific $\lg _{1}$ and $\operatorname{lgG}_{2 b}$ in the sera of animals immunized with $\mathrm{G}_{6 \mathrm{PI}_{325-339}}$ (Figure 4).

\section{Discussion}

In the present article we describe the identification of two novel peptides derived from human G6PI, which are arthritogenic in DBA/1 mice. In addition, we confirm the report by 


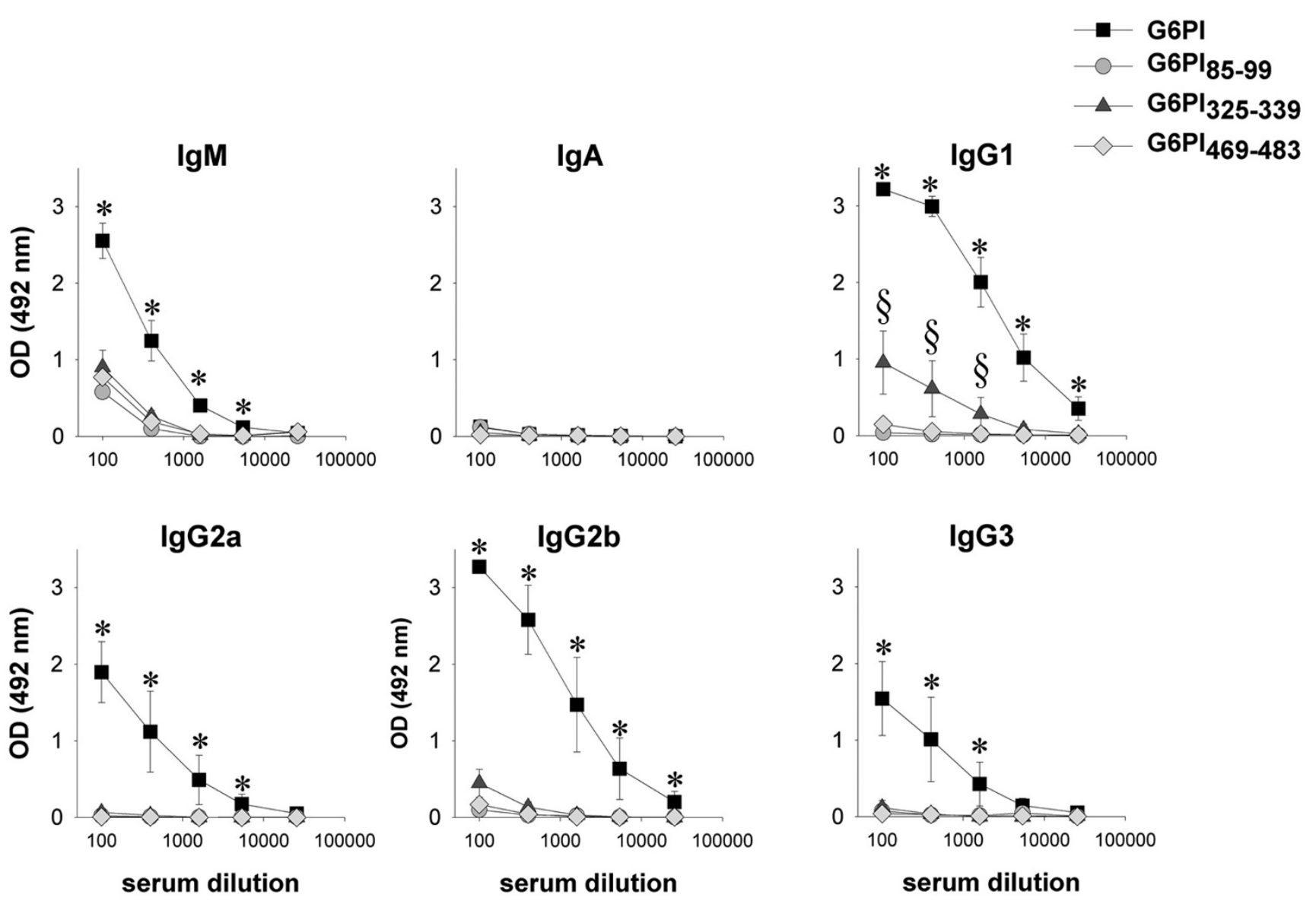

Analysis of glucose-6-phosphate-specific immunoglobulin production. DBA/1 mice were immunized with either $400 \mu \mathrm{g}$ glucose-6-phosphate $(\mathrm{G} 6 \mathrm{PI}), 50 \mu \mathrm{g} \mathrm{G} \mathrm{PI}_{85-99}, 50 \mu \mathrm{g} \mathrm{G} \mathrm{PPI}_{325-339} \mathrm{Or} 50 \mu \mathrm{g} \mathrm{G} \mathrm{PI}_{469-483}$ in complete Freund's adjuvant. Mice were sacrificed on day 12 after immunization and titers of $\mathrm{G} 6 \mathrm{PI}$-specific immunoglobulins of the indicated isotypes were measured by ELISA. Data are representative of at least two different

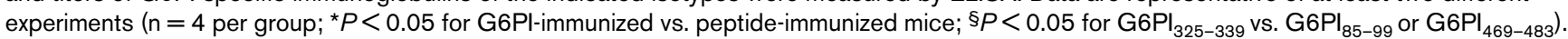
OD, optical density.

Iwanami and colleagues identifying $\mathrm{G} \mathrm{PI}_{325-339}$ as an arthritogenic peptide [30]. The peptide sequence of $\mathrm{G}_{6 \mathrm{PI}} \mathrm{H}_{49-483}$ is identical in man and mouse. G6Pl-induced arthritis is therefore currently the only mouse model in which arthritis can be induced by immunization with a peptide derived from a selfantigen.

Our screen identified at least six G6PI peptides that are immunodominant for I-Aq-restricted T-cell responses. The T-cell response towards the ubiquitously expressed autoantigen G6PI is therefore not focused on one dominant epitope. Instead, at least three peptide-epitopes derived from G6PI are immunodominant and arthritogenic in DBA/1 mice. There is precedence for several immunodominant antigens within one protein for $\mathrm{T}$-cell responses restricted towards one particular $\mathrm{MHC}$ molecule [31]. For hen egg lysozyme, which consists of only 129 amino acids, there are at least six dominant peptide epitopes for $\mathrm{I}-\mathrm{A}^{\mathrm{k}}$-restricted $\mathrm{T}$-cell responses alone [32].

The different number of peptides identified by Iwanami and colleagues [30] and in the present report reflects the fundamentally different approaches to identifying immunodominant G6PI epitopes. Iwanami and colleagues examined known sequences of I-Aq-restricted T-cell epitopes and deduced a possible I-Aq binding motif from these sequences. Peptides derived from G6PI that fit this possible I-Aq binding motif were then synthesized and tested. These peptides covered 399/ $558(71.5 \%)$ amino acid residues of the human GPI protein. Consequently, as acknowledged by Iwanami and colleagues [30], this approach carries the risk of missing relevant peptide epitopes. Moreover, several groups including ours have shown previously that several peptides that do not fit the consensus sequence for peptides binding to a given $\mathrm{MHC}$ molecule can activate $\mathrm{T}$ cells restricted to that $\mathrm{MHC}$ molecule very efficiently 
[33-36]. We therefore took an unbiased approach. To identify the immunodominant epitopes we used a set of $15 \mathrm{mer}$ peptides overlapping by 11 amino acids that span the whole sequence of human $\mathrm{G} 6 \mathrm{PI}$. Neither $\mathrm{G} \mathrm{PI}_{85-99}$ nor $\mathrm{G} \mathrm{PI}_{469-483}$ were predicted by the algorithm used by Iwanami and colleagues [30], and neither of these two peptides fits the binding motif for $\mathrm{I}-\mathrm{A} q$ that has been suggested by Holm and colleagues based on their analysis of 24 I-Aq-binding peptides [37] again supporting the use of unbiased approaches to epitope identification.

Whereas these considerations explain how Iwanami and col-

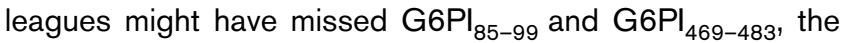
fact that our analyses did not identify $\mathrm{G}_{6 \mathrm{Pl}}{ }_{325-339}$ still needs

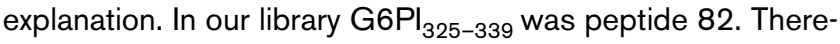
fore it was included in Pools 10 and 19. While peptide Pool 10 scored positive in all three experiments, Pool 19 scored positive only once - therefore peptide 82 , which occurred in these two pools, was initially not synthesized for further analyses. There are several possible reasons for the altogether weak proliferation data obtained from Pool 19, including the possibility that agonist and weak antagonist peptides contained within such a pool could cancel out one another [38]. Nevertheless, unbiased large peptide libraries have been used very successfully to identify T-cell epitopes [33-36].

Another difference between our findings and those reported by Iwanami and colleagues [30] is the kinetic and clinical severity of arthritis induced by peptide as compared with arthritis induced by G6PI protein. In our hands, peptideinduced arthritis occurs somewhat delayed and with lower incidence and clinical severity than G6PI-induced arthritis. Iwanimi and colleagues report no difference in arthritis severity and onset between peptide-immunized and protein-immunized mice. This difference is most probably due to the fact that our immunization protocol uses antigen in CFA subcutaneously for both peptide and protein immunization, whereas Iwanami and colleagues use intradermal injection of peptide in CFA followed by two injections of pertussis toxin intraperitoneally at days 0 and 2 relative to immunization [30]. In fact, Iwanami and colleagues report on lower incidence and severity of arthritis when they omit pertussis toxin. Both groups observe substantially lower G6PI-specific antibody titers in the peptide-immunized mice as compared with G6Pl-immunized mice. Given we have shown earlier that $F c \gamma R$ is critical for arthritis development [21], it seems likely that the low antibody concentrations detectable in the serum are sufficient to contribute to the milder form of arthritis induced upon peptide immunization. Moreover, it has been reported that pathogenic antibodies against $\mathrm{G} 6 \mathrm{PI}$ attach to cartilage and therefore accumulate in the joints $[39,40]$.

The number of antigen-specific Th cells was similar in the draining lymph nodes of peptide-immunized or protein-immunized mice. We used CD154 expression to identify G6PI-spe- cific Th cells. CD154 expression is rapidly upregulated upon T-cell receptor signaling, and CD154 expression has been shown to be a sensitive and specific marker to identify $T$ cells specific for a defined antigen [28,29,41-43]. To examine the $\mathrm{G} 6 \mathrm{PI}-$ specific cytokine responses, we determined the frequency of cytokine producers among the CD4+CD154+ Th cells upon in vitro culture with antigen. Perhaps unexpectedly, the frequency of cytokine producers among the antigen-specific Th cells was higher in the peptide-immunized mice than in the protein-immunized mice. In addition there were also differences among the mice immunized with different peptides. For example, the highest frequency of IL-17-producing CD4 ${ }^{+} \mathrm{CD} 154^{+}$cells was found in the draining lymph nodes of mice immunized with $\mathrm{G}_{6 \mathrm{Pl}} \mathrm{85-99}_{\text {. }}$. Caution is warranted in interpreting fine quantitative differences among the different groups. Several confounding parameters, including different antigen-processing requirements for full-length G6PI protein or peptides, dissimilar kinetics of the responses and the differing solubility of individual G6PI peptides, make it difficult to compare quantitatively the frequency of cytokine-producing $T h$ cells in response to G6PI or peptides in the different groups of mice.

Our data add RANKL to the list of cytokines that are prominently produced by G6PI-specific Th cells. IL-6 is a therapeutic target in juvenile idiopathic arthritis and rheumatoid arthritis in humans [44]. It is also produced upon polyclonal stimulation of $\mathrm{T}$ cells from G6PI-immunized mice [21]. Matsumoto and coworkers recently found that IL- 6 was relevant for the pathogenesis of G6PI-induced arthritis [24,25]. Interestingly, IL-6 is not produced by G6PI-specific Th cells directly ex vivo upon culture with either $\mathrm{G} 6 \mathrm{PI}$ or $\mathrm{G} 6 \mathrm{PI}$ peptides. Cells other than the G6PI-specific Th cells must therefore produce the pathogenetically relevant IL-6 in G6PI-induced arthritis. B cells, which are required for the pathogenesis of $\mathrm{G} 6 \mathrm{PI}$-induced arthritis [22] and also for rheumatoid arthritis $[45,46]$, are potent producers of IL-6. It shall be interesting to determine which cell population provides the pathogenic IL-6 in G6PI as well as in rheumatoid arthritis. Except for the different kinetics, the pattern of Th-cell cytokine production is very similar in G6PIimmunized and $\mathrm{G}_{6} \mathrm{Pl}_{85-99}$-immunized mice. Compared with these two groups, the $\mathrm{G} 6 \mathrm{PI}_{469-483}$-immunized mice harbor much fewer $\mathrm{CD} 4{ }^{+} \mathrm{CD} 154^{+}$cytokine producers. This does not seem to correlate with the incidence and severity of arthritis, which is very similar in $\mathrm{G}_{6 \mathrm{PI}} \mathrm{85-99}$-immunized mice and $\mathrm{G} 6 \mathrm{PI}_{469-483}$-immunized mice.

\section{Conclusions}

In the present article we describe the identification of six immunodominant G6PI peptides that induce T-cell responses in DBA/1 mice. Immunization with three of these peptides induces peripheral symmetric polyarthritis with high incidence. One of the peptides $\left(\mathrm{G}_{6 \mathrm{PI}} \mathrm{H69-483}\right)$ is an autoantigen. We have therefore described for the first time arthritis in mice induced by immunization with a self-peptide. 


\section{Competing interests}

The authors declare that they have no competing interests.

\section{Authors' contributions}

LB and OF participated in the in vivo studies, the T-cell assays and the ELISA studies, and drafted parts of the manuscript. LM performed the histopathological analyses. CL and RV prepared the peptide libraries, the peptides and participated in designing the peptide pools. TK conceived of the study and participated in its design and coordination, and wrote the manuscript. All authors read and approved the final manuscript.

\section{Acknowledgements}

The authors thank Kai Kaufmann, Caroline Bocklisch, Gabriele Fernahl and Christine Baier for excellent technical assistance, and thank Bärbel Matz and Regina Musack for expert mouse care. The present work was supported by the Interdisciplinary Centre for Clinical Research (IZKF) Jena - Pathogenesis and Modulation of G6Pl-induced Arthritis (to TK), and Pathogenic and Protective Role of T helper Cells in Arthritis (to OF) - and by the ENDO-Stiftung-Gemeinnütziger Verein ENDO-Klinik e.V. (to $\mathrm{LM}$ ). The present work forms part of the PhD thesis of LB.

\section{References}

1. Kamradt T, Mitchison NA: Tolerance and autoimmunity. N Engl J Med 2001, 344:655-664.

2. The Wellcome Trust Case Control Consortium: Genome-wide association study of 14,000 cases of seven common diseases and 3,000 shared controls. Nature 2007, 447:661-678

3. Plenge RM, Seielstad M, Padyukov L, Lee AT, Remmers EF, Ding B, Liew A, Khalili H, Chandrasekaran A, Davies LR, Li W, Tan AK, Bonnard C, Ong RT, Thalamuthu A, Pettersson S, Liu C, Tian C, Chen WV, Carulli JP, Beckman EM, Altshuler D, Alfredsson L, Criswell LA, Amos Cl, Seldin MF, Kastner DL, Klareskog L, Gregersen PK: TRAF1-C5 as a risk locus for rheumatoid arthritis - a genomewide study. N Engl J Med 2007, 357:1199-1209.

4. Klareskog L, Catrina Al, Paget S: Rheumatoid arthritis. Lancet 2009, 373:659-672.

5. Lundy SK, Sarkar S, Tesmer LA, Fox DA: Cells of the synovium in rheumatoid arthritis. T lymphocytes. Arthritis Res Ther 2007, 9:202.

6. Firestein GS: Evolving concepts of rheumatoid arthritis. Nature 2003, 423:356-361.

7. Genovese MC, Schiff M, Luggen M, Becker JC, Aranda R, Teng J, Li T, Schmidely N, Le Bars M, Dougados M: Efficacy and safety of the selective co-stimulation modulator abatacept following 2 years of treatment in patients with rheumatoid arthritis and an inadequate response to anti-tumour necrosis factor therapy. Ann Rheum Dis 2008, 67:547-554.

8. Kremer JM, Genant HK, Moreland LW, Russell AS, Emery P, AbudMendoza C, Szechinski J, Li T, Teng J, Becker JC, Westhovens R: Results of a two-year followup study of patients with rheumatoid arthritis who received a combination of abatacept and methotrexate. Arthritis Rheum 2008, 58:953-963.

9. Jirholt J, Lindqvist $A B$, Holmdahl R: The genetics of rheumatoid arthritis and the need for animal models to find and understand the underlying genes. Arthritis Res 2001, 3:87-97.

10. Berg WB van den, Joosten LA, van Lent PL: Murine antigeninduced arthritis. Methods Mol Med 2007, 136:243-253.

11. Holmdahl R, Bockermann R, Backlund J, Yamada H: The molecular pathogenesis of collagen-induced arthritis in mice - a model for rheumatoid arthritis. Ageing Res Rev 2002, 1:135-147.

12. Cremer MA, Ye XJ, Terato K, Owens SW, Seyer JM, Kang AH: Type XI collagen-induced arthritis in the Lewis rat. Characterization of cellular and humoral immune responses to native types XI, V, and II collagen and constituent alpha-chains. J Immunol 1994, 153:824-832.
13. Carlsen S, Hansson AS, Olsson H, Heinegard D, Holmdahl R: Cartilage oligomeric matrix protein (COMP)-induced arthritis in rats. Clin Exp Immunol 1998, 114:477-484.

14. Glant TT, Finnegan A, Mikecz K: Proteoglycan-induced arthritis: immune regulation, cellular mechanisms, and genetics. Crit Rev Immunol 2003, 23:199-250.

15. Bayrak S, Holmdahl R, Travers P, Lauster R, Hesse M, Dolling R, Mitchison NA: T cell response of I-Aq mice to self type II collagen: meshing of the binding motif of the I-Aq molecule with repetitive sequences results in autoreactivity to multiple epitopes. Int Immunol 1997, 9:1687-1699.

16. Buzas El, Vegvari A, Murad YM, Finnegan A, Mikecz K, Glant TT: $T$-cell recognition of differentially tolerated epitopes of cartilage proteoglycan aggrecan in arthritis. Cell Immunol 2005, 235:98-108.

17. Brand DD, Myers LK, Terato K, Whittington KB, Stuart JM, Kang $\mathrm{AH}$, Rosloniec EF: Characterization of the T cell determinants in the induction of autoimmune arthritis by bovine alpha 1(II)CB11 in H-2q mice. J Immunol 1994, 152:3088-3097.

18. Holmdahl R, Jansson L, Larsson A, Jonsson R: Arthritis in DBA/1 mice induced with passively transferred type II collagen immune serum. Immunohistopathology and serum levels of anti-type II collagen auto-antibodies. Scand J Immunol 1990, 31:147-157.

19. Stuart JM, Tomoda K, Yoo TJ, Townes AS, Kang AH: Serum transfer of collagen-induced arthritis. II. Identification and localization of autoantibody to type II collagen in donor and recipient rats. Arthritis Rheum 1983, 26:1237-1244.

20. Terato K, Hasty KA, Reife RA, Cremer MA, Kang AH, Stuart JM: Induction of arthritis with monoclonal antibodies to collagen. $J$ Immunol 1992, 148:2103-2108.

21. Schubert D, Maier B, Morawietz L, Krenn V, Kamradt T: Immunization with glucose-6-phosphate isomerase induces $\mathrm{T}$ celldependent peripheral polyarthritis in genetically unaltered mice. J Immunol 2004, 172:4503-4509.

22. Bockermann R, Schubert D, Kamradt T, Holmdahl R: Induction of a B-cell-dependent chronic arthritis with glucose-6-phosphate isomerase. Arthritis Res Ther 2005, 7:R1316-R1324.

23. Kamradt $T$, Schubert $D$ : The role and clinical implications of G6PI in experimental models of rheumatoid arthritis. Arthritis Res Ther 2005, 7:20-28.

24. Iwanami K, Matsumoto I, Tanaka-Watanabe $\mathrm{Y}$, Inoue A, Mihara M, Ohsugi $Y$, Mamura M, Goto D, Ito S, Tsutsumi A, Kishimoto T, Sumida $T$ : Crucial role of the interleukin-6/interleukin-17 cytokine axis in the induction of arthritis by glucose-6-phosphate isomerase. Arthritis Rheum 2008, 58:754-763.

25. Matsumoto I, Zhang H, Yasukochi T, Iwanami K, Tanaka Y, Inoue A, Goto D, Ito S, Tsutsumi A, Sumida T: Therapeutic effects of antibodies to tumor necrosis factor-alpha, interleukin- 6 and cytotoxic T-lymphocyte antigen 4 immunoglobulin in mice with glucose-6-phosphate isomerase induced arthritis. Arthritis Res Ther 2008, 10:R66.

26. Lunemann JD, Frey O, Eidner T, Baier M, Roberts S, Sashihara J, Volkmer R, Cohen JI, Hein G, Kamradt T, Munz C: Increased frequency of EBV-specific effector memory $\mathrm{CDB}^{+} \mathrm{T}$ cells correlates with higher viral load in rheumatoid arthritis. J Immunol 2008, 181:991-1000.

27. Krenn V, Morawietz L, Haupl T, Neidel J, Petersen I, Konig A: Grading of chronic synovitis - a histopathological grading system for molecular and diagnostic pathology. Pathol Res Pract 2002, 198:317-325.

28. Frentsch M, Arbach O, Kirchhoff D, Moewes B, Worm M, Rothe M, Scheffold A, Thiel A: Direct access to $\mathrm{CD}^{+}{ }^{+} \mathrm{T}$ cells specific for defined antigens according to CD154 expression. Nat Med 2005, 11:1118-1124.

29. Chattopadhyay PK, Yu J, Roederer M: A live-cell assay to detect antigen-specific $\mathrm{CD} 4^{+} \mathrm{T}$ cells with diverse cytokine profiles. Nat Med 2005, 11:1113-1117.

30. Iwanami K, Matsumoto I, Tanaka Y, Inoue A, Goto D, Ito S, Tsutsumi $A$, Sumida T: Arthritogenic $T$ cell epitope in glucose-6phosphate isomerase-induced arthritis. Arthritis Res Ther 2008, 10:R130.

31. Roy S, Scherer MT, Briner TJ, Smith JA, Gefter ML: Murine MHC polymorphism and $\mathrm{T}$ cell specificities. Science 1989, 244:572-575.

32. Gammon G, Klotz J, Ando D, Sercarz EE: The T cell repertoire to a multideterminant antigen. Clonal heterogeneity of the T cell 
response, variation between syngeneic individuals, and in vitro selection of $T$ cell specificities. J Immunol 1990, 144:1571-1577.

33. Grogan JL, Kramer A, Nogai A, Dong L, Ohde M, Schneider-Mergener J, Kamradt T: Cross-reactivity of myelin basic proteinspecific $T$ cells with multiple microbial peptides: experimental autoimmune encephalomyelitis induction in TCR transgenic mice. J Immunol 1999, 163:3764-3770.

34. Hemmer B, Gran B, Zhao Y, Marques A, Pascal J, Tzou A, Kondo T, Cortese I, Bielekova B, Straus SE, McFarland HF, Houghten R, Simon R, Pinilla C, Martin R: Identification of candidate T-cell epitopes and molecular mimics in chronic Lyme disease. Nat Med 1999, 5:1375-1382.

35. Maier B, Molinger M, Cope AP, Fugger L, Schneider-Mergener J, Sonderstrup G, Kamradt T, Kramer A: Multiple cross-reactive self-ligands for Borrelia burgdorferi-specific HLA-DR4restricted T cells. Eur J Immunol 2000, 30:448-457.

36. Nino-Vasquez JJ, Allicotti G, Borras E, Wilson DB, Valmori D, Simon R, Martin R, Pinilla C: A powerful combination: the use of positional scanning libraries and biometrical analysis to identify cross-reactive T cell epitopes. Mol Immunol 2004, 40:1063-1074.

37. Holm L, Frech K, Dzhambazov B, Holmdahl R, Kihlberg J, Linusson A: Quantitative structure-activity relationship of peptides binding to the class II major histocompatibility complex molecule $\mathrm{Aq}$ associated with autoimmune arthritis. I Med Chem 2007, 50:2049-2059.

38. Kamradt T, Volkmer-Engert R: Cross-reactivity of T lymphocytes in infection and autoimmunity. Mol Divers 2004, 8:271-280.

39. Wipke BT, Wang Z, Kim J, McCarthy TJ, Allen PM: Dynamic visualization of a joint-specific autoimmune response through positron emission tomography. Nat Immunol 2002 , 3:366-372.

40. Studelska DR, Mandik-Nayak L, Zhou X, Pan J, Weiser P, McDowell LM, Lu H, Liapis H, Allen PM, Shih FF, Zhang L: High affinity glycosaminoglycan and autoantigen interaction explains joint specificity in a mouse model of rheumatoid arthritis. J Biol Chem 2009, 284:2354-2362.

41. Huaman MC, Martin LB, Malkin E, Narum DL, Miller LH, Mahanty $S$, Long CA: Ex vivo cytokine and memory T cell responses to the 42-kDa fragment of Plasmodium falciparum merozoite surface protein-1 in vaccinated volunteers. J Immunol 2008, 180:1451-1461.

42. Mittrucker HW Steinhoff $U$, Kohler A, Krause M, Lazar D, Mex $P$ Miekley D, Kaufmann SH: Poor correlation between BCG vaccination-induced $T$ cell responses and protection against tuberculosis. Proc Natl Acad Sci USA 2007, 104:12434-12439.

43. Stubbe M, Vanderheyde N, Pircher H, Goldman M, Marchant A: Characterization of a subset of antigen-specific human central memory $\mathrm{CD}^{+} \mathrm{T}$ lymphocytes producing effector cytokines. Eur J Immunol 2008, 38:273-282.

44. Nishimoto N, Kishimoto T: Interleukin 6: from bench to bedside. Nat Clin Pract Rheumatol 2006, 2:619-626.

45. Browning JL: B cells move to centre stage: novel opportunities for autoimmune disease treatment. Nat Rev Drug Discov 2006, 5:564-576.

46. Martin F, Chan AC: B cell immunobiology in disease: evolving concepts from the clinic. Annu Rev Immuno/ 2006, 24:467-496. 